\title{
Pengaruh Perputaran Aktiva, Perputaran Kas dan Loan to Deposit Ratio (LDR) terhadap Return on Asset (ROA) pada Perbankan yang terdaftar di Bursa Efek Indonesia pada Tahun 2013-2017
}

\author{
Mahmuddin Syah Lubis \\ Universitas Prima Indonesia \\ Mahmuddinsyah@gmail.com \\ Mery \\ Universitas Prima Indonesia \\ Meryling614@yahoo.com \\ Vini Yulia \\ Universitas Prima Indonesia \\ Viniyulia2@gmail.com
}

\author{
Isna Asdiani Nasution \\ Universitas Prima Indonesia \\ Isnanasution@gmail.com \\ Jenvony \\ Universitas Prima Indonesia \\ Jenvony@gmail.com \\ Vivi Devika \\ Universitas Prima Indonesia \\ viviciahui@gmail.com
}

Vivi Novera

Universitas Prima Indonesia

Vivinovera12345@gmail.com

\begin{abstract}
This study aims to test and analyze the effect of asset turnover, cash turnover and the Loan to Deposit Ratio (LDR) on Returns on Assets (ROA) in Banking listed on the Indonesia Stock Exchange in 2013-2017. This study uses a quantitative research approach, the type of descriptive research and the nature of research is causal relationships. The population of this study was 43, the study sample was 23 with 5 years of observation so that the samples obtained were as many as 115. The analytical method used was multiple linear regression, $F$ test and $T$ test. The partial results of the study were influential and significant asset turnover and cash turnover towards Return On Assets (ROA), Loan to Deposit Ratio (LDR) has an effect to Return On Assets (ROA). Simultaneously asset turnover, cash turnover and Loan to Deposit Ratio (LDR) have an effect on and significant to Return On Assets (ROA)

Keywords: Asset Turnover, Cash Turnover, Loan to Deposit Ratio (LDR) and Retrun On Asset (ROA).
\end{abstract}

\begin{abstract}
ABSTRAK
Penelitian ini bertujuan untuk menguji dan menganalisis pengaruh perputaran aktiva, perputaran kas dan Loan to Deposit Ratio (LDR) Terhadap Return On Asset (ROA) Pada Perbankan yang terdaftar di Bursa Efek Indonesia Pada Tahun 2013-2017. Penelitian ini menggunakan pendekatan penelitian
\end{abstract}


kuantitatif, jenis penelitian deskriptif dan sifat penelitian yaitu hubungan kausal. Populasi penelitian ini adalah 43, sampel penelitian sebanyak 23 dengan 5 tahun pengamatan sehingga sampel yang diperoleh yaitu sebanyak 115. Metode analisis yang digunakan adalah regresi linear berganda, uji $\mathrm{F}$ dan uji T. Hasil penelitian secara parsial adalah perputaran aktiva dan perputaran kas berpengaruh dan signifikan terhadap Return On Asset (ROA), Loan to Deposit Ratio (LDR) berpengaruh Terhadap Return On Asset (ROA) .Secara simultan perputaran aktiva, perputaran kas dan Loan to Deposit Ratio (LDR) berpengaruh dan signifikan terhadap Return On Asset (ROA).

Kata Kunci : Perputaran aktiva, perputaran kas, Loan to Deposit Ratio (LDR) dan Return On Asset (ROA).

\section{PENDAHULUAN}

\subsection{Latar Belakang}

Perbankan dipandang sebagai inti dari sistem perekonomian di setiap negara dimana arus ekonomi dan keuangan mengalir di dalamnya. Hal ini terkait dengan fungsi utama bank sebagai penghimpun dana dari masyarakat yang selanjutnya akan disalurkan kembali ke masyarakat dalam bentuk penanaman dana melalui kredit. Faktor penentu ROA (Return On Asset) dapat dilihat dari faktor internalnya yang meliputi kecukupan modal, efisiensi operasional, likuditas dan ukuran aset. Karena dari faktor internal menggambarkan kondisi bank dan kinerja bank selama menjalankan aktifitasnya

$$
\text { Perusahaan perbankan }
$$
memiliki aktiva yang dipergunakan untuk membayar kewajiban perusahaannya. Aktiva itu dibagi menjadi dua yaitu: aktiva lancar dan aktiva tetap. Aktiva tetap dibagi menjadi dua golongan yaitu, aktiva tetap berwujud dan aktiva tidak berwujud. Aktiva ini yang akan digunakan perusahaan untuk memperoleh return on asset (ROA).
Perputaran kas merupakan hal yang sangat penting bagi sebuah perusahaan karena merupakan rasiorasio yang digunakan dalam mengukur efisiensi modal kerja dalam sebuah perusahaan. Adanya modal kerja yang cukup atau cukupnya kas dalam perusahaan akan memudahkan perusahaan tersebut dalam melakukan aktifitas sehingga tidak menimbulkan masalah.

\section{Rasio Loan To Deposit Ratio} (LDR) digunakan untuk mengukur kemampuan bank tersebut mampu membayar hutang-hutangnya dan membayar kembali kepada deposannya, serta dapat memenuhi permintaan kredit yang diajukan. Besarnya jumlah kredit yang disalurkan akan menentukan keuntungan bank, jika bank tidak mampu menyalurkan kredit sementara dana yang terhimpun banyak maka akan menyebabkan bank tersebut rugi. Jumlah kredit yang diberikan semakin besar, maka akan membawa konsekuensi semakin besarnya risiko yang harus ditanggung oleh bank. Loan to Deposit Ratio (LDR) dijadikan rasio perbandingan antara jumlah dana 
yang disalurkan ke masyarakat dalam bentuk kredit, dengan jumlah dana masyarakat dan modal sendiri yang digunakan.

\subsection{Tujuan Penelitian}

Berdasarkan uraian yang telah ada sebelumnya dapat dirumuskan tujuan

penelitian sebagai berikut :

1. Untuk menguji dan menganalisis pengaruh perputaran aktiva Terhadap Return On Asset (ROA) Pada Perbankan yang terdaftar di Bursa Efek Indonesia Pada Tahun 2013-2017.

2. Untuk menguji dan menganalisis pengaruh perputaran kas Terhadap Return OnAsset (ROA) Pada Perbankan yang terdaftar di Bursa Efek Indonesia Pada Tahun 2013-2017.

3. Untuk menguji dan menganalisis pengaruh Loan to Deposit Ratio (LDR) Terhadap Return On Asset (ROA) Pada Perbankan yang terdaftar di Bursa Efek Indonesia Pada Tahun 2013-2017.

4. Untuk menguji dan menganalisis pengaruh perputaran aktiva, perputaran kas dan Loan to Deposit Ratio (LDR) Terhadap Return On Asset (ROA) Pada Perbankan yang terdaftar di Bursa Efek Indonesia Pada Tahun 20132017.

\subsection{Permasalahan}

Penelitian sebelumnya yang dilakukan oleh Indriyani, Panjaitan dan Yenfi (2017) yang melakukan penelitian dengan judul "Analisis Pengaruh Current Ratio dan Total
Asset Turnover Terhadap Return On Asset (Studi Kasus Pada PT Pelabuhan Indonesia II (Persero) Cabang Pangkalbalam)". Secara parsial menunjukkan pengaruh negatif antara Current Ratio terhadap Return On Asset dan Total Asset Turnover berpengaruh positif terhadap Return On Asset. Secara simultan Current Ratio dan Total Asset Turnover berpengaruh terhadap Return On Asset.

Yulistiani dan Suryantini (2016) yang melakukan penelitian dengan judul "Pengaruh Perputaran Kas, Kecukupan Modal Dan Risiko Operasi Terhadap Profitabilitas Pada Perusahaan Perbankan Di BEI". Secara parsial Perputaran kas berpengaruh positif dan signifikan terhadap profitabilitas. Kecukupan modal berpengaruh negatif dan tidak signifikan terhadap profitabilitas. Risiko operasi berpengaruh negatif dan signifikan terhadap profitabilitas. Secara simultan Perputaran kas, kecukupan modal dan risiko operasi berpengaruh terhadap profitabilitas.

Agustiningrum (2013) yang melakukan penelitian dengan judul "Analisis Pengaruh Car, NPL, LDR Terhadap Profitabilitas Pada Perusahaan Perbankan". Secara parsial NPL berpengaruh negatif dan LDR berpengaruh positif terhadap profitabilitas, sedangkan CAR tidak berpengaruh terhadap profitabilitas.

\section{KAJIAN PUSTAKA \\ 2.1 Perputaran aktiva}

Menurut Hery (2016:99) perputaran total aset merupakan rasio yang digunakan untuk mengukur keefektifan total aset yang dimiliki 
perusahaan dalam menghasilkan penjualan, atau dengan kata lain untuk mengukur berapa jumlah penjualan yang akan dihasilkan dari setiap rupiah dana yang tertanam dalam total aset.

Menurut Suartika, dkk (2013:90), aktiva tetap dalam hal ini secara parsial berpengaruh signifikan terhadap laba, karena aktiva tetap merupakan aktiva yang dimiliki oleh perusahaan dengan nilai yang cukup besar dan tidak untuk dijual kembali serta dominan harus diperhitungkan oleh perusahaan, karena aktiva tetap juga mampu menghasilkan laba jika dapat digunakan secara efisien.

\subsection{Perputaran kas}

Menurut Halim (2015:166), cash turnover merupakan berapa kali uang kas berputar selama suatu periode. Semakin besar cash turnover, semakin kecil jumlah kas yang dibutuhkan dalam operasional perusahaan.

Menurut Riyanto (2016:94), kas adalah salah satu unsur modal kerja yang paling tinggi tingkat likuiditasnya. Makin besar jumlah kas yang ada di dalam perusahaan berarti makin tinggi tingkat likuiditasnya. Ini berarti bahwa perusahaan mempunyai risiko yang lebih kecil untuk tidak dapat memenuhi kewajiban finansialnya.

\subsection{Loan to deposit ratio}

Menurut Pandia (2012:128) Loan to Deposit Ratio (LDR) adalah rasio yang menyatakan seberapa jauh bank telah menggunakan uang para penyimpan (depositor) untuk memberikan pinjaman kepada para nasabahnya. Dengan kata lain jumlah uang yang dipergunakan untuk member pinjaman adalah uang yang berasal dari titipan para penyimpan.

Menurut Kasmir (2013:242), bagi perbankan atau lembaga keuangan lainnya bahwa kemampuan untuk menyalurkan dana melalui pinjaman merupakan suatu keharusan, hal ini disebabkan bahwa kegiatan perbankan memang memberikan pinjaman. Jadi, apabila perusahaan tidak mampu memberikan atau meningkatkan jumlah pinjaman maka akan membahayakan kehidupan bank.

\subsection{Return on asset}

Menurut Fahmi (2015:185), ROA atau sering juga disebut dengan return on Assets adalah rasio ini melihat sejauhmana investasi yang telah ditanamkan mampu memberikan pengembalian keuntungan sesuai dengan yang diharapkan.

\section{METODE PENELITIAN 3.1 Pendekatan Penelitian}

Penelitian ini menggunakan pendekatan penelitian kuantitatif. Menurut Sugiyono (2012:13), Penelitian kuantitatif dapat diartikan sebagai metode penelitian yang digunakan untuk meneliti pada populasi atau sampel tertentu, teknik pengambilan sampel pada umumnya dilakukan secara random, pengumpulan data menggunakan instrumen penelitian, analisis data bersifat kuantitatif/statistik dengan tujuan untuk menguji hipotesis yang telah ditetapkan.

\subsection{Jenis Penelitian}


Jenis penelitian ini adalah penelitian deskriptif. Menurut Sanusi (2012:13), penelitian deskriptif adalah suatu bentuk penelitian yang disusun dalam rangka memberikan gambaran secara sistematis tentang informasi yang berasal dari subjek atau objek penelitian. Penelitian deskrtiptif berfokus pada penjelasan sistematis tentang fakta yang diperoleh saat penelitian dilakukan.

\subsection{Sifat Penelitian}

Penelitian ini bersifat explanatory. Menurut Zulganef (2013:11), penelitian explanatory adalah penelitian yang bertujuan menelaah kausalitas antar variabel yang menjelaskan suatu fenomena tertentu.

\subsection{Populasi dan Sampel}

Menurut Sugiyono (2012:115) populasi adalah wilayah generalisasi yang terdiri atas obyek/subyek yang mempunyai kualitas dan karakteristik tertentu yang ditetapkan oleh peneliti untuk dipelajari dan kemudian ditarik kesimpulannya. Populasi penelitian ini adalah 43 Perbankan yang terdaftar di BEI Pada Tahun 2013-2017. Menurut Sugiyono (2012:116) Sampel adalah bagian dari jumlah dan karakteristik yang dimiliki oleh populasi tersebut. Penarikan sampel dilakukan dengan purposive sampling method. Menurut Sugiyono (2012:122) Purposive sampling method adalah teknik penentuan sampel dengan pertimbangan tertentu. Dalam penelitian ini, kriteria yang ditetapkan adalah sebagai berikut:

1. Perbankan yang terdaftar di BEI Pada Tahun 2013-2017.
2. Perbankan menerbitkan laporan keuangan auditor independen selama tahun 2013-2017.

3. Perbankan yang memiliki laba selama tahun 2013-2017.

Tabel 1. Kriteria Pengambilan Sampel Penelitian

\begin{tabular}{|c|c|c|}
\hline No & Kriteria & $\begin{array}{l}\text { Jumlah } \\
\text { Sampel }\end{array}$ \\
\hline 1. & $\begin{array}{l}\text { Perbankan yang terdaftar } \\
\text { di BEI Pada Tahun 2013- } \\
2017 .\end{array}$ & 43 \\
\hline 2 & \begin{tabular}{lc|}
$\begin{array}{l}\text { Perbankan } \\
\text { menerbitkan }\end{array}$ & $\begin{array}{c}\text { tidak } \\
\text { keuangan }\end{array}$ \\
auditor independen selama \\
tahun 2013-2017.
\end{tabular} & (13) \\
\hline 3 & $\begin{array}{l}\text { Perbankan yang tidak } \\
\text { memiliki laba selama tahun } \\
\text { 2013-2017. }\end{array}$ & (7) \\
\hline \multicolumn{2}{|r|}{ Jumlah Sampel Perusahaan } & 23 \\
\hline & Total Sampel (5 x 23) & 115 \\
\hline
\end{tabular}

\subsection{Teknik Pengumpulan Data}

Teknik pengumpulan data yang digunakan dalam penelitian ini yaitu :

1. Tinjauan pustaka berupa bukubuku yang dapat digunakan sebagai bahan rujukan dalam penelitian ini. Menurut Sanusi (2012:32) buku-buku teks merupakan sumber utama yang pada umumnya menjadi sasaran peneliti untuk memperoleh informasi ilmiah yang relevan dengan masalah penelitian. Bukubuku teks ini biasanya tersimpan di perpustakaan di lembaga pendidikan maupun lembaga pemerintahan dan lembaga bisnis.

2. Menurut Sugiyono (2012:422) dokumen merupakan catatan peristiwa yang sudah berlalu. Dokumentasi berupa dokumen yang diperoleh dari situs www.idx.co.id yakni laporan 
keuangan Perbankan yang terdaftar di BEI Pada Tahun 20132017.

\subsection{Jenis dan Sumber Data}

Menurut Sugiyono (2012:18), penelitian kuantitatif dalam melihat hubungan variabel terhadap obyek yang diteliti lebih bersifat sebab dan akibat/kausal, sehingga dalam penelitiannya ada variabel independen dan dependen. Dari variabel tersebut selanjutnya dicari seberapa besar pengaruh variabel independen terhadap variabel dependen. Jenis data yang digunakan dalam penelitian ini adalah data sekunder.

\section{Menurut}

(2012:402), Sumber sekunder merupakan sumber yang tidak langsung memberikan data kepada pengumpul data, misalnya lewat orang lain atau lewat dokumen. Sumber data yang digunakan peneliti adalah data sekunder yang berupa laporan keuangan Perbankan yang terdaftar di BEI Pada Tahun 20132017 dengan website www.idx.co.id.

\subsection{Definisi Operasional Variabel}

Variabel dependen dalam Penelitian ini adalah Return On Asset (ROA). Menurut Pandia (2012:71) rumus Return on assets yang digunakan adalah :

$R O A=\frac{\text { Laba sebelum pajak }}{\text { Total aktiva }} \times 100 \%$

Variabel dependen dalam penelitian ini adalah:

1. Perputaran Aktiva
Menurut Kasmir (2011:186) rumus untuk mencari total asset turnover adalah sebagai berikut :

$$
\text { Perputaran aktiva }=\frac{\text { Penjualan }}{\text { Total aktiva }}
$$

2. Perputaran kas

Menurut Hery (2012:24), untuk menghitung perputaran kas dapat digunakan rumus sebagai berikut :

Perputaran kas $=\frac{\text { Penjualan bersih }}{\text { Rata-rata kas dan setara kas }}$

3. Loan to deposit ratio

Menurut Pandia (2012:128), penilaian kesehatan likuiditas bank yang berupa LDR sebagai berikut :

$$
L D R=\frac{\text { Kredit }}{\text { Dana pihak ketiga }} \times 100 \%
$$

\subsection{Kerangka Konseptual}

Berdasarkan uraian yang telah ada sebelumnya dapat digambarkan kerangka konseptual yang dapat dilihat :

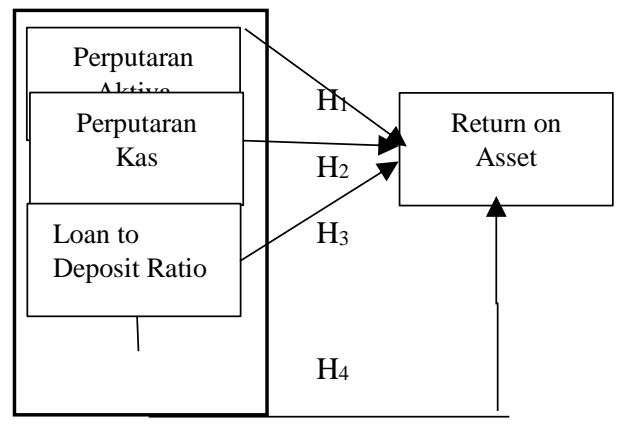

Gambar 1 Kerangka Konseptual

Berdasarkan kerangka konseptual, maka hipotesis penelitian ini adalah sebagai berikut :

$\mathrm{H}_{1}$ : Perputaran aktiva berpengaruh Terhadap Return On Asset (ROA) Pada Perbankan yang 
terdaftar di Bursa Efek Indonesia Pada Tahun 20132017.

$\mathrm{H}_{2}$ : Perputaran kas berpengaruh Terhadap Return On Asset (ROA) Pada Perbankan yang terdaftar di Bursa Efek Indonesia Pada Tahun 20132017.

$\mathrm{H}_{3}$ : Loan to Deposit Ratio (LDR) berpengaruh Terhadap Return On Asset (ROA) Pada Perbankan yang terdaftar di Bursa Efek Indonesia Pada Tahun 2013-2017.

$\mathrm{H}_{4}$ : Perputaran aktiva, perputaran kas dan Loan to Deposit Ratio (LDR) berpengaruh Terhadap Return On Asset (ROA) Pada Perbankan yang terdaftar di Bursa Efek Indonesia Pada Tahun 2013-2017.

\section{HASIL DAN PEMBAHASAN 4.1 Statistik Deskriptif}

Sampel pada penelitian ini adalah berjumlah 23 dengan periode penelitian dari tahun 2013-2017 sehingga data yang diperoleh adalah berjumlah 115 data penelitian.

Tabel 2. Statistik Deskriptif

\begin{tabular}{|c|c|c|c|c|c|}
\hline \multicolumn{6}{|c|}{ Descriptive Statistics } \\
\hline & $\mathrm{N}$ & Minimum & Maximum & Mean & St. Deviation \\
\hline PerputaranAlktiva & 115 & .04 & .23 & .0881 & .01951 \\
\hline PerputaranKas & 115 & 1,58 & 81,44 & 10,2330 & 9,29023 \\
\hline LDR & 115 & 42,12 & 102,21 & 82,4340 & 13,83912 \\
\hline $\mathrm{ROA}$ & 115 & .11 & 5,40 & 1,8375 & 1,13884 \\
\hline Valid N (listwise) & 115 & & & & \\
\hline $\begin{array}{l}\text { Sumber : } \\
\text { (2019) }\end{array}$ & & 10 & an & ta & enulis \\
\hline
\end{tabular}

\subsection{Uji Asumsi Klasik}

\section{Uji normalitas}

Uji normalitas bertujuan untuk menguji apakah dalam model regresi,residual memiliki distribusi normal. Hasil uji normalitas dapat berupa tabel statistik Kolmogorov Smirnov. Dalam uji ini, pedoman yang digunakan dalam pengambilan keputusan adalah :

a. Jika nilai signifikan lebih besar dari 0,05 maka distribusi normal.

b. Jika nilai signifikan lebih kecil dari 0,05 maka distribusi tidak normal.

Tabel 3. Uji Normalitas

\begin{tabular}{|c|c|c|}
\hline \multicolumn{3}{|c|}{$\begin{array}{c}\text { menggunakan Kolmogorov Sm } \\
\text { One-Sample Kolmogorov-Smirnov Test }\end{array}$} \\
\hline & & $\begin{array}{l}\text { Unstandardized } \\
\text { Residual }\end{array}$ \\
\hline $\mathrm{N}$ & & 115 \\
\hline \multirow[t]{2}{*}{ Normal Parametersas: } & Mean & 0 \\
\hline & $\begin{array}{l}\text { S td. } \\
\text { Deviation }\end{array}$ & 1,01178604 \\
\hline \multirow{3}{*}{$\begin{array}{l}\text { Most Extreme } \\
\text { Differences }\end{array}$} & Absolvte & 0,08 \\
\hline & Positive & 0,08 \\
\hline & Neg ative & $-0,046$ \\
\hline Test S taristic & & 0,08 \\
\hline Asymp. Sig. (2-tailed) & &, 065 \\
\hline \multicolumn{3}{|c|}{ a. Test distribution is Normal. } \\
\hline $\begin{array}{l}\text { b. Calculated from data. } \\
\text { c. Lilliefors Significance }\end{array}$ & orrection. & \\
\hline
\end{tabular}

Sumber : Hasil Pengolahan data Penulis (2019)

\section{Uji multikolinearitas}

Uji multikolinearitas bertujuan untuk menguji apakah pada model regresi ditemukan adanya korelasi antar variable independen. Model regresi yang baik seharusnya tidak terjadi korelasi antar variabel independen. Cara pengambilan keputusan yaitu :

a. Nilai tolerance $\leq 0.10$

b. Nilai VIP $\geq 10$.

Tabel 4. Uji Multikolinearitas Coefficients $^{\mathrm{a}}$ 


\begin{tabular}{llr|r} 
& & \multicolumn{2}{c}{ Collinearity Statistics } \\
Model & & Tolerance & \multicolumn{1}{c}{ VIF } \\
\hline 1 & & & \\
\cline { 2 - 4 } & (Constant) &, 960 & 1,042 \\
\cline { 2 - 4 } & PerputaranAktiva &, 964 & 1,037 \\
\cline { 2 - 4 } & PerputaranKas &, 976 & 1,025 \\
\cline { 2 - 4 } & LDR & .970 \\
\hline
\end{tabular}

Sumber : Hasil Pengolahan data Penulis (2019)

\section{Uji autokorelasi}

Uji autokorelasi bertujuan menguji apakah dalam model regresi linear ada korelasi antara kesalahan pengganggu pada periode $\mathrm{t}$ dengan kesalahan penganggu pada periode t1 (sebelumnya).

Jika terjadi korelasi, maka dinamakan ada problem autokorelasi. Salah satu ukuran dalam menentukan ada tidaknya masalah autokorelasi dengan uji Durbin-Watson (DWtest). Berikut hasil uji auto korelasi dengan uji Durbin-Watson :

a. Bila angka DW $<-2$ berarti ada autokorelasi yang positif

b. Bila angka DW - 2 sampai dengan +2 berarti tidak adaautokorelasi

c. Bila angka DW $>+2$ berarti ada autokorelasi yang negatif.

Tabel 5. Uji Autokorelasi dengan

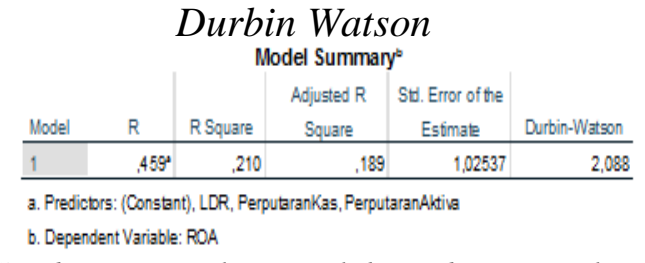

Sumber : Hasil Pengolahan data Penulis (2019)

\section{Uji heterokedastisitas}

Uji Heteroskedastisitas berguna untuk menguji apakah dalam model regresi terjadi ketidaksamaan varian dari residual satu pengamatan ke pengamatan yang lain.
Pendeteksian ada tidaknya heteroskedastisitas dalam penelitian ini menggunakan Uji glejser.

Jika variabel independen signifikan secara statistik mempengaruhi variabel dependen, maka ada indikasi terjadi heteroskedastisitas.

Tabel 6. Hasil Pengujian

Heterokedastisitas dengan Uji

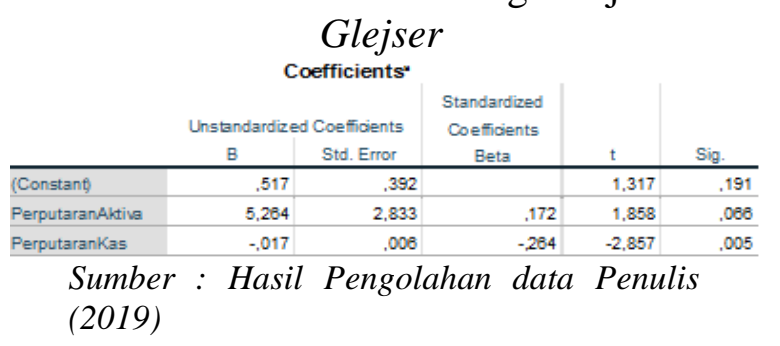

\subsection{Hasil Analisis Data Penelitian 1. Model penelitian}

Pengujian hipotesis yang digunakan dalam penelitian adalah dengan menggunakan analisis regresi linier berganda.

Tabel 7. Model Penelitian

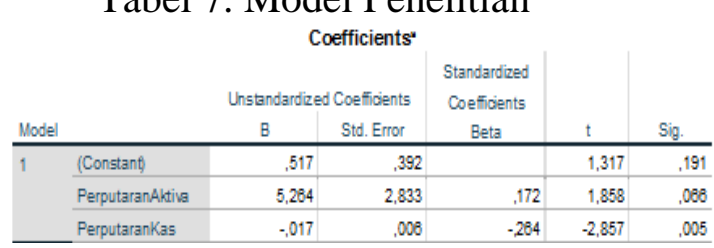

Sumber : Hasil Pengolahan data Penulis (2019)

Model regresi yang digunakan adalah sebagai berikut :

ROA $=-0,426+15,620$ Perputaran Aktiva $-0,040$ Perputaran Kas + 0,016 LDR

Adapun makna dari persamaan regresi linier berganda diatas adalah :

a. Nilai a sebesar -0,426 satuan menyatakan bahwa jika variabel perputaran aktiva, perputaran kas dan Loan to Deposit Ratio (LDR) 
bernilai nol maka Return On Asset (ROA) adalah sebesar 0,426 satuan.

b. Nilai koefisien variabel perputaran aktiva sebesar 15,620 satuan dan bernilai positif menyatakan bahwa setiap kenaikan perputaran aktiva 1 satuan akan menyebabkan kenaikan Return On Asset (ROA) sebesar 15,620 satuan.

c. Nilai koefisien variabel perputaran kas adalah $-0,040$ satuan dan bernilai positif menyatakan bahwa setiap peningkatan perputaran kas 1 satuan akanmenyebabkan penurunan Return On Asset (ROA) sebesar 0,040 satuan.

d. Nilai koefisien variabel Loan to Deposit Ratio (LDR) adalah 0,016 satuan dan bernilai positif menyatakan bahwa setiap kenaikan Loan to Deposit Ratio (LDR) 1 satuan akan menyebabkan kenaikan Return On Asset (ROA) sebesar 0,016 satuan.

\section{Koefisien determinasi}

Uji koefisien determinasi digunakan untuk mengukur seberapa besar kemampuan pengaruh variabel bebas dapat menjelaskan variabel terikat. Semakin besar nilai koefisien determinasi, maka semakin baik kemampuan varian dan variabel bebas menerangkan variabel terikat.

Tabel 8. Koefisien Determinasi Hipotesis Model Summary

\begin{tabular}{lr|r|r|r} 
Model & R & R Square & \multicolumn{1}{c|}{$\begin{array}{c}\text { Adjusted R } \\
\text { Square }\end{array}$} & $\begin{array}{c}\text { St. Error of the } \\
\text { Estmate }\end{array}$ \\
\hline 1 & $.459^{\circ}$ &, 210 &, 189 & 1,02537 \\
\hline
\end{tabular}

a. Predictors: (Constant), LDR, PerputaranKas, PerputaranAktiva

b. Dependent Variable: ROA

Sumber : Hasil Pengolahan data Penulis (2019)

Hasil nilai adjusted R Square (R2) koefisien determinasi sebesar 0,189 atau sama dengan $18,9 \%$. Dengan tingkat $18,9 \%$, jadi variabel independen berpengaruh terhadap Return On Asset (ROA) sebesar $18,9 \%$. Dan sisanya $81,1 \%$ dipengaruhi oleh variabel lain seperti Net Interest Margin, Capital Adequacy Ratio (CAR) dan Biaya Operasional Pendapatan Operasional.

\section{Uji F}

Untuk menguji hipotesis ini digunakan statistik $\mathrm{F}$ dengan keputusan sebagai berikut :

a. Jika Fhitung > Ftabel atau sig < 0,05, maka $\mathrm{H} 0$ ditolak dan $\mathrm{Ha}$ diterima

b. Jika Ftabel $\leq$ Fhitung, atau sig $\geq$ 0,05, maka $\mathrm{Ha}$ ditolak dan $\mathrm{H} 0$ diterima

c.

Tabel 9. Uji

\begin{tabular}{|c|c|c|c|c|c|c|}
\hline \multicolumn{7}{|c|}{ ANOVA* } \\
\hline Model & & Sum of Squares & df & Mean Square & $\mathrm{F}$ & Sig. \\
\hline \multirow[t]{2}{*}{1} & Regression & 31,098 & 3 & 10,386 & 9,859 & $.000^{\circ}$ \\
\hline & Residual & 116,703 & 111 & 1,051 & & \\
\hline
\end{tabular}

Sumber : Hasil Pengolahan data Penulis (2019)

Hasil Fhitung adalah sebesar 9,859> nilai Ftabel $(115-4=111)$ adalah sebesar 2,69 maka Ho ditolak dan $\mathrm{Ha}$ diterima dengan nilai signifikan $0,000<0,05$ sehingga Perputaran aktiva, perputaran kas dan Loan to Deposit Ratio (LDR) berpengaruh dan signifikan terhadap Return On Asset (ROA) Pada 
Perbankan yang terdaftar di Bursa Efek Indonesia Pada Tahun 20132017.

\section{Uji t}

Uji t digunakan untuk menguji apakah variabel independen secara individal mempengaruhi variabel dependen Uji ini dilakukan dengan membandingkan nilai signifikasi dengan ketentuan sebagai berikut :

a. Jika -ttabel $\leq$ thitung $\leq$ ttabel atau

Sig $\geq \alpha=0,05$, maka Ha ditolak dan $\mathrm{H} 0$ diterima.

b. Jika thitung $>$ ttabel atau -thitung $\leq-$ tabel atau $\operatorname{Sig} \geq \alpha=0,05$, maka H0 ditolak dan Ha diterima. c.

Tabel 10. Uji T

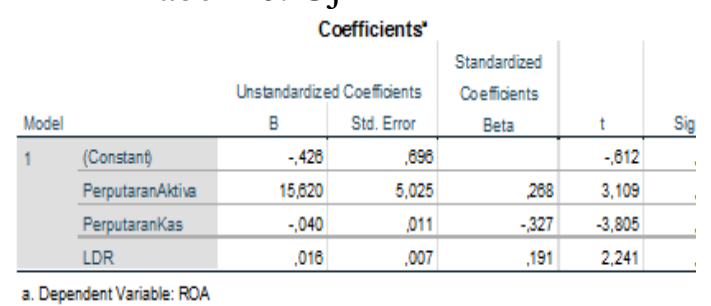

Sumber : Hasil Pengolahan data Penulis (2019)

Dimana :

a. Perputaran Aktiva mempunyai nilai thitung adalah sebesar 3,109 > 1,981 maka Ho ditolak dan Ha diterima dengan nilai signifikan $0,002<0,05$ sehingga Perputaran aktiva berpengaruh dan signifikan terhadap Return On Asset (ROA) Pada Perbankan yang terdaftar di Bursa Efek Indonesia Pada Tahun 2013-2017.

b. Perputaran Kas mempunyai nilai thitung adalah sebesar $-3,805<-$ 1981 maka Ho ditolak dan Ha diterima dengan nilai signifikan $0,000<0,05$ sehingga Perputaran kas berpengaruh dan signifikan terhadap Return On Asset (ROA) Pada Perbankan yang terdaftar di Bursa Efek Indonesia Pada Tahun 2013-2017.

c. Loan to Deposit Ratio (LDR) mempunyai nilai thitung adalah sebesar 2,241>1,981 maka Ho ditolak dan $\mathrm{Ha}$ diterima dengan nilai signifikan $0,027<0,05$ sehingga Loan to Deposit Ratio (LDR) berpengaruh Terhadap Return On Asset (ROA) Pada Perbankan yang terdaftar di Bursa Efek Indonesia Pada Tahun 20132017.

\subsection{PEMBAHASAN}

Pengaruh perputaran aktiva terhadap return on asset

Perputaran aktiva

berpengaruh dan signifikan terhadap Return On Asset (ROA) Pada Perbankan yang terdaftar di Bursa Efek Indonesia Pada Tahun 20132017.

Hasil penelitian sejalan dengan penelitian Indriyani, Panjaitan dan Yenfi (2017), yang menyatakan Total Asset Turnover dengan Return On Asset terdapat pengaruh yang positif.

Hasil penelitian ini sesuai dengan teori Rangkuti (2012:334335), karena perusahaan semakin dapat memanfaatkan setiap rupiah aktiva untuk menghasilkan penjualan.

\section{Pengaruh perputaran kas terhadap return on asset}

Perputaran kas berpengaruh dan signifikan terhadap Return On Asset (ROA) Pada Perbankan yang 
terdaftar di Bursa Efek Indonesia Pada Tahun 2013-2017.

Hasil penelitian ini sejalan dengan replikasi penelitian Yulistiani dan Suryantini (2016) yang menyatakan Perputaran kas berpengaruh positif dan signifikan terhadap profitabilitas.

Hasil penelitian tidak sesuai dengan teori Riyanto (2016:94), kas adalah salah satu unsur modal kerja yang paling tinggi tingkat likuiditasnya. Makin besar jumlah kas yang ada di dalam perusahaan berarti makin tinggi tingkat likuiditasnya. Ini berarti bahwa perusahaan mempunyai risiko yang lebih kecil untuk tidak dapat memenuhi kewajiban finansialnya.

\section{Pengaruh loan to deposit ratio terhadap return on asset}

Loan to Deposit Ratio (LDR) berpengaruh Terhadap Return On Asset (ROA) Pada Perbankan yang terdaftar di Bursa Efek Indonesia Pada Tahun 2013-2017.

Hasil penelitian ini sejalan
dengan replikasi penelitian
menyatakan LDR berpengaruh positif terhadap ROA.

Hasil penelitian sesuai dengan teori Kasmir (2013:242), bagi perbankan atau lembaga keuangan lainnya bahwa kemampuan untuk menyalurkan dana melalui pinjaman merupakan suatu keharusan, hal ini disebabkan bahwa kegiatan perbankan memang memberikan pinjaman. Jadi, apabila perusahaan tidak mampu memberikan atau meningkatkan jumlah pinjaman maka akan membahayakan kehidupan bank, demikian pula sebaliknya apabila mampu memenuhi target kredit yang disalurkan baik jumlah dana maupun jumlah debiturnya, maka merupakan keberhasilan, bagi perusahaan tersebut.

\section{KESIMPULAN SARAN \\ Kesimpulan}

Kesimpulan hasil penelitian ini adalah :

1. Perputaran aktiva berpengaruh secara parsial terhadap Return On Asset (ROA) Pada Perbankan yang terdaftar di Bursa Efek Indonesia Pada Tahun 20132017.

2. Perputaran kas berpengaruh secara parsial terhadap Return On Asset (ROA) Pada Perbankan yang terdaftar di Bursa Efek Indonesia Pada Tahun 2013-2017.

3. Loan to Secara Parsial Loan to Deposit Ratio (LDR) berpengaruh secara parsial Terhadap Return On Asset (ROA) Pada Perbankan yang terdaftar di Bursa Efek Indonesia Pada Tahun 2013-2017.

4. Perputaran aktiva, perputaran kas dan Loan to Deposit Ratio (LDR) berpengaruh secara simultan terhadap Return On Asset (ROA) Pada Perbankan yang terdaftar di bursa efek Indonesia Pada Tahun 2013-2017.

\section{Saran}

Adapun saran dari hasil penelitian ini adalah:

1. Pihak manajemen perusahaan sebaik meningkatkan Return On Asset (ROA) perbankan dengan cara meningkatkan perputaran 
aktiva yang dimiliki perusahaan, mempercepat perputaran kas dan meningkatkan Loan to Deposit Ratio (LDR) yang disalurkan ke masyarakat.

2. Bagi peneliti selanjutnya menggunakan variabel independen lain yang mempengaruhi Return On Asset (ROA) dan memperpanjang tahun pengamatan serta mengganti perusahaan pengamatan.

3. Sebaiknya hasil penelitian dapat menjadi tambahan bahan kepustakaan di Universitas Prima Indonesia dan berguna menjadi bahan referensi bagi mahasiswa lainnya.

\section{DAFTAR RUJUKAN}

Agustiningrum, Riski. 2013. Analisis Pengaruh Car, NPL, LDR Terhadap Profitabilitas Pada Perusahaan Perbankan. E-Jurnal Manajemen Universitas Udayana, p-ISSN:2302-8912.

Defri. 2012. Pengaruh Capital Adequacy Ratio (CAR), Likuiditas dan Efisiensi Operasional Terhadap Profitabilitas Perusahaan Perbankan yang Terdaftar di BEI. Jurnal Manajemen, Volume 01, Nomor 01, September 2012.

Fahmi, Irham. 2015. Manajemen Perbankan Konvensional \& Syariah. Jakarta : Penerbit Mitra4 Wacana Media.

Halim, Abdul. 2015. Manajemen Keuangan Bisnis Konsep dan Aplikasinya. Jakarta : Penerbit Mitra Wacana Media.
Hery. 2012. Analisis Laporan Keuangan. Cetakan Pertama. Jakarta : Penerbit Bumi Aksara.

Indriyani, Panjaitan dan Yenfi. 2017. Analisis Pengaruh Current Ratiodan Total Asset Turnover Terhadap Return On Asset (Studi Kasus Pada PT Pelabuhan Indonesia II (Persero) Cabang Pangkalbalam). Jurnal Ilmiah Akuntansi Bisnis \& Keuangan (JIABK), Volume 10, Nomor 2, November 2017. Pangkal Pinang : STIE-IBEK Bangka Belitung.

Kasmir. 2013. Pengantar Manajemen Keuangan. Edisi Pertama. Jakarta : Penerbit Kencana.

Pandia, Frianto. 2012. Manajemen Dana Dan Kesehatan Bank. Jakarta : Penerbit Rineka Cipta.

Rangkuti, Freddy. 2012. Studi Kelayakan Bisnis \& Investasi Studi Kasus. Jakarta : PT. Gramedia Pustaka Utama.

Riyanto, Bambang. 2016. Dasardasar Pembelanjaan Perusahaan. Edisi Keempat. Cetakan Keenam. Yogyakarta : Penerbit BPFE Yogyakarta.

Sanusi, Anwar. 2012. Metodologi Penelitian Bisnis. Cetakan Ketiga. Jakarta : Penerbit Salemba Empat.

Suartika, dkk. 2013. Pengaruh Aktiva Tetap, Hutang Jangka Panjang, dan Modal terhadap Laba Bersih Perusahaan Agribisnis Indeks LQ 45 yang Terdaftar di Bursa Efek Indonesia. Jurnal Manajemen Agribisnis. Vol. 1, No. 2, Oktober 2013. ISSN: 23550759. 
Sugiyono. 2012. Metode Penelitian Manajemen. Jakarta : Penerbit CV Alfabeta.

Yulistiani dan Suryantini. 2016.

Pengaruh Perputaran Kas,

Kecukupan Modal Dan

Risiko Operasi Terhadap

Profitabilitas Pada

Perusahaan Perbankan Di

BEI. E-Jurnal Manajemen

Unud. Bali : Universitas

Udayana (Unud).

Zulganef. 2013. Metode Penelitian

Sosial dan Bisnis, Ed. 1

Cetakan kedua. Yogyakarta :

Graha Ilmu. 